\title{
Analysis of the Stimulating Action of Tolbutamide on the Secretion of Insulin Using Mannoheptulose and Diazoxide
}

\author{
M.M. Loubatières-Mariani, A.L. Loubatières and J. Chapal \\ Institut de Biologie, Montpellier, France
}

Received: August 15, 1972, accepted: December 22, 1972

\begin{abstract}
Summary. The stimulating action of tolbutamide on insulin secretion presents two components; the first is independent of the presence of glucose in the medium which perfuses the beta cells; the second is, on the contrary, dependent upon glucose. D-mannoheptulose and diazoxide permit the dissociation of these two components; the antagonistic effect of the first exerts itself uniquely on that part of the stimulating action of
\end{abstract}

tolbutamide which is gluco-dependent; on the contrary, the antagonistic effect of the second exerts itself on both phases of the stimulating action of the sulfonamide.

Key words: Insulin-secretion, tolbutamide, sulfonylurea hypoglycemic sulfonamide, mannoheptulose, diazoxide, isolated perfused rat pancreas.
The aim of this work was to analyze the mechanism of the stimulating action of tolbutamide on the secretion of insulin. It was carried out on the isolated and perfused rat pancreas. Some of our results have been previously reported [12].

The stimulating action of tolbutamide has been studied first in the absence of glucose in the perfusion medium and secondly in the presence of a moderately stimulating concentration of glucose $(1.5 \mathrm{~g} / \mathrm{l})$.

We then studied how this stimulation could be modified by two substances known to have an inhibitory action on the secretion of insulin: D-mannoheptulose and diazoxide.

\section{Technique}

The technique used has been previously described [10]. The pancreases were taken from Wistar rats weighing about $350 \mathrm{~g}$.

The perfusion medium consisted of Krebs-Ringer bicarbonate buffer. Purified beef albumin $(2 \mathrm{~g} / \mathrm{l})$ was added to the buffer; a mixture of oxygen $(93 \%)$ and carbon dioxide $(7 \%)$ was then bubbled through this liquid at atmospheric pressure. The $\mathrm{pH}$ of the solution was $\simeq 7.3$.

The Insulin was assayed in the efferent fluid from the pancreas using the radio-immunological method B of Hales and Randle [4]. The standard used was pure rat insulin whose biological activity was $19 \mu \mathrm{U} / \mathrm{ng}$.

In all experiments there was an adaptation period of thirty minutes between the time when the organ was perfused and the time when the first sample used for the assay of insulin was collected. The pancreas was perfused with the physiological buffer containing glucose $(1.5 \mathrm{~g} / \mathrm{l})$ for $45 \mathrm{~min}$. At this time, two types of experiments were carried out: glucose was either eliminated from the perfusion medium until the end of the experiment or maintained at the same concentration $(1.5 \mathrm{~g} / 1)$
On the graphs, the time is counted from the moment when the organ was perfused. Our results are expressed as variations of the insulin output; these variations are expressed as percentages in relation to the insulin secretion rate recorded at the 45 th $\mathrm{min}$, which constituted the reference point. The insulin secretion rates were measured for each sample and for each pancreas by multiplying the insulin concentration $(\mathrm{ng} / \mathrm{ml})$ by the perfusion flow rate $(\mathrm{ml} / \mathrm{min})$. The insulin secretion rate of the pancreases at the reference time was on average $38.9 \mathrm{ng} / \mathrm{min}$.

\section{Results}

\section{The insulin secretory effect of tolbutamide alone}

In these experiments this substance was perfused for $30 \mathrm{~min}$ at a concentration of $108 \mathrm{mg} / \mathrm{l}$ or $0.4 \mathrm{mM}$. The following facts were noted:

1. When the perfusion medium did not contain glucose, tolbutamide provoked (Figure 1 - graph A) a stimulation of the secretion of insulin which took place in two phases: an immediate, important phase whose maximum was approximately one minute after the start and which lasted less than $8 \mathrm{~min}$; it was followed by a phase of stimulation that was much less intense but prolonged. In this second phase, the secretion of insulin was higher than the basal secretion normally obtained in the absence of glucose. Therefore, tolbutamide presents, in the absence of glucose, a direct stimulating action on the beta cell of the islets of Langerhans.

2. On the other hand, when tolbutamide acted in the presence of glucose $(1.5 \mathrm{~g} / 1)$ in the perfusion medium (Figure 1 - graph B), there also appeared an extremely rapid stimulation of insulin secretion (first phase). The height of the first peak of insulin secretion was not significantly different from that obtained in the ab- 
sence of glucose. During the second phase however, the secretion of insulin was much greater than that observed in the absence of glucose. Its height is close to that of the initial peak of insulin secretion.

\section{Modification of the action of tolbutamide by $D$ - mannoheptulose}

D-mannoheptulose, a carbohydrate with seven carbon atoms that inhibits the phosphorylation of glucose, opposes the stimulation of the secretion of insulin provoked by this substance $[1,2]$.

We have examined the effects of increasing concentrations of D-mannoheptulose on the secretion of insulin induced by glucose $(1.5 \mathrm{~g} / 1)$. Figure 2 - graph A shows the effects provoked by D-mannoheptulose at concentrations between $5 \mathrm{mg} / 1(0.0236 \mathrm{mM})$ and $2 \mathrm{~g} / \mathrm{l}$ $(9.44 \mathrm{mM})$. Graph B of the same figure represents the dose-effect curve obtained.

The inhibitory effect begins to manifest itself at very low concentrations of mannoheptulose, $5 \mathrm{mg} / \mathrm{l}$ $(0.0236 \mathrm{mM})$. At a concentration of $500 \mathrm{mg} / \mathrm{l}(2.36$ $\mathrm{mM}$ ), the secretion of insulin is practically the same as that in the absence of glucose.

Having determined the concentrations of Dmannoheptulose capable of opposing the stimulating effect of glucose under our experimental conditions, we studied how this carbohydrate would be capable of modifying the action of tolbutamide. In these experiments, mannoheptulose was introduced into the perfusion liquid $15 \mathrm{~min}$ before the hypoglycemic sulfonamide.

1. In the case where the pancreas was perfused with a liquid not containing glucose, we observed (Figure 3graph A) that mannoheptulose at a concentration of $0.5 \mathrm{~g} / 1$ (the concentration which opposed the stimulation provoked by glucose) did not modify the secretion provoked by tolbutamide.

2. Using a pancreas perfused by a liquid containing glucose, mannoheptulose was used at two concentrations: $0.5 \mathrm{~g} / \mathrm{l}$ and $2 \mathrm{~g} / \mathrm{l}$. The results obtained are represented on figure 3 - graph B.

At a concentration of $0.5 \mathrm{~g} / \mathrm{l}$ (which totally inhibited the insulin secretory effect of glucose) mannoheptulose did not lower the initial rapid and intense phase of insulin secretion provoked by tolbutamide but did lower considerably the second phase. In these experiments, the pancreas behaved, under the influence of tolbutamide, as if it were perfused by a solution not containing glucose. The concentration of mannoheptalose four times greater than that used previously $(2 \mathrm{~g} / \mathrm{l})$ neither modified appreciably this behaviour nor diminished the level of the first phase of secretion.

According to these two series of experiments, mannoheptulose therefore allows the glucose-independent part of the stimulating action of tolbutamide to persist.

\section{Modifications of the action of tolbutamide by dia- zoxide}

Diazoxide is a sulfonamide whose chemical strueture is close to that of tolbutamide but the sulfonamide function is introduced in a benzothiadiazine ring. This substance is hyperglycemic and inhibits the secretion of insulin. It was, therefore, interesting to examine in a third group of experiments how diazoxide would oppose the stimulating action that tolbutamide exerts on the secretion of insulin.

1. First, we investigated the effect of diazoxide on the secretion provoked by tolbutamide when glucose was absent from the perfusion medium.

In this series of experiments, an infusion of diazoxide $(0.5 \mathrm{mM}$ or $115 \mathrm{mg} / \mathrm{l})$ preceded by two minutes the infusion of tolbutamide $(0.4 \mathrm{mM}$ or $108 \mathrm{mg} / \mathrm{l})$.

As is shown in figure 4 (graph A), it turned out that diazoxide was capable of completely inhibiting the two phases of insulin secretion normally provoked by tolbutamide under identical experimental conditions. Therefore, diazoxide opposed that part of the stimulating action of tolbutamide not dependent upon the presence of glucose in the medium.

2. Next, we undertook the study of how diazoxide would be capable of modifying the stimulating action of tolbutamide when it acts in the presence of glucose (1.5 $\mathrm{g} / \mathrm{l})$.

We perfused a pancreas with increasing concentrations of diazoxide (between $23 \mathrm{mg} / \mathrm{l}$ or $0.1 \mathrm{mM}$ and $184 \mathrm{mg} / \mathrm{l}$ or $0.8 \mathrm{mM})$ and added tolbutamide $(108 \mathrm{mg} / \mathrm{l}$ or $0.4 \mathrm{mM}$ ) $15 \mathrm{~min}$ later.

From the results shown in Figure 4 (graph B), we can see that, as the concentration of diazoxide increased, the stimulation provoked by tolbutamide diminished. This diminution concerned the two phases of insulin secretion; however, the second phase was relatively more reduced.

Therefore, diazoxide totally opposed the stimulating action of tolbutamide; it opposed not only the action of tolbutamide that was independent of glucose but equally that dependent on the presence of glucose in the perfusion medium.

\section{Discussion}

It has now been demonstrated and acknowledged that the hypoglycemic sulfonamides possess a stimulating action on the secretion of insulin. We have attempted, with these experiments, to study more deeply the mechanisms involved in this action. The results obtained permit us to arrive at the following conclusion:

Tolbutamide exerts, even if glucose is not present in the medium, a direct stimulating action on the beta cell of the islets of Langerhans (Figure 1). This results in an intense, rapid and short lasting secretion reaching a 

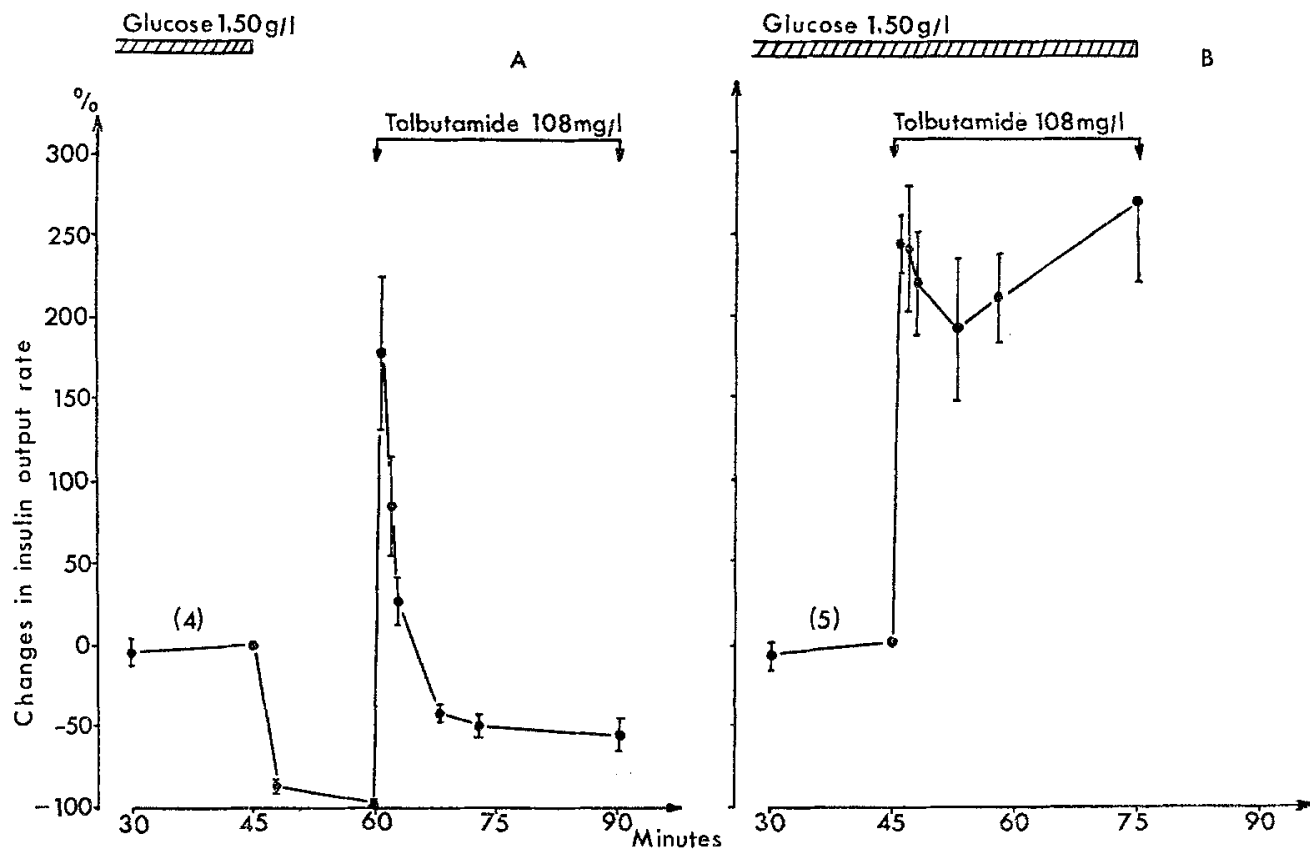

Fig. 1. Effect of tolbutamide $(108 \mathrm{mg} / \mathrm{l}) 0.4 \mathrm{mM}$ on the secretion of insulin by the isolated perfused rat pancreas, on one hand in the absence of glucose in the perfusion medium (Graph A), on the other hand in the presence of glucose $(1.5 \mathrm{~g} / 1)$ (Graph B). Each point represents the mean of the values obtained and carries the standard error of the mean. The number of pancreases is indicated in parenthesis
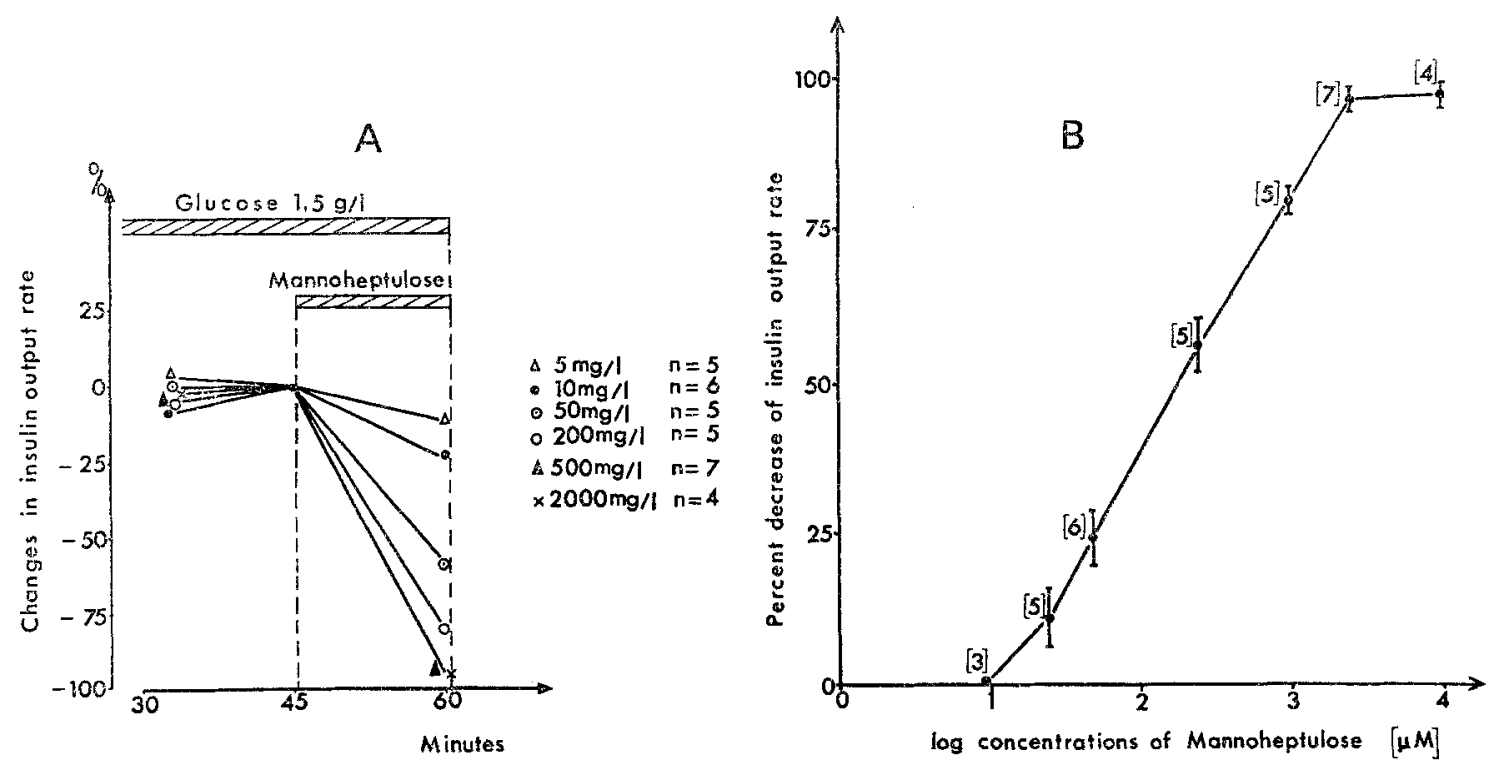

Fig. 2. Graph A shows the inhibitory effect of increasing concentrations of D-mannoheptulose on the secretion of insulin induced by glucose $(1.5 \mathrm{~g} / \mathrm{l})$ in the isolated and perfused rat pancreas. ( $\mathrm{n}=$ Number of pancreases). Graph $\mathrm{B}$ represents the dose-response curve. The percent decrease was ealculated after a 15 min infusion of mannoheptulose, in relation to the value recorded immediately before the infusion. The concentrations used are: $9.44 \mu \mathrm{M}(2 \mathrm{mg} / \mathrm{l})-$ $23.6 \mu \mathrm{M}(5 \mathrm{mg} / \mathrm{l})-47.2 \mu \mathrm{M}(10 \mathrm{mg} / \mathrm{l})-236 \mu \mathrm{M}(50 \mathrm{mg} / \mathrm{l})-944 \mu \mathrm{M}(200 \mathrm{mg} / \mathrm{l})-2360 \mu \mathrm{M}(500 \mathrm{mg} / 1)-9440 \mu \mathrm{M}$ $(2000 \mathrm{mg} / 1)$. The number of pancreases used for the establishment of each point is indicated in parenthesis 

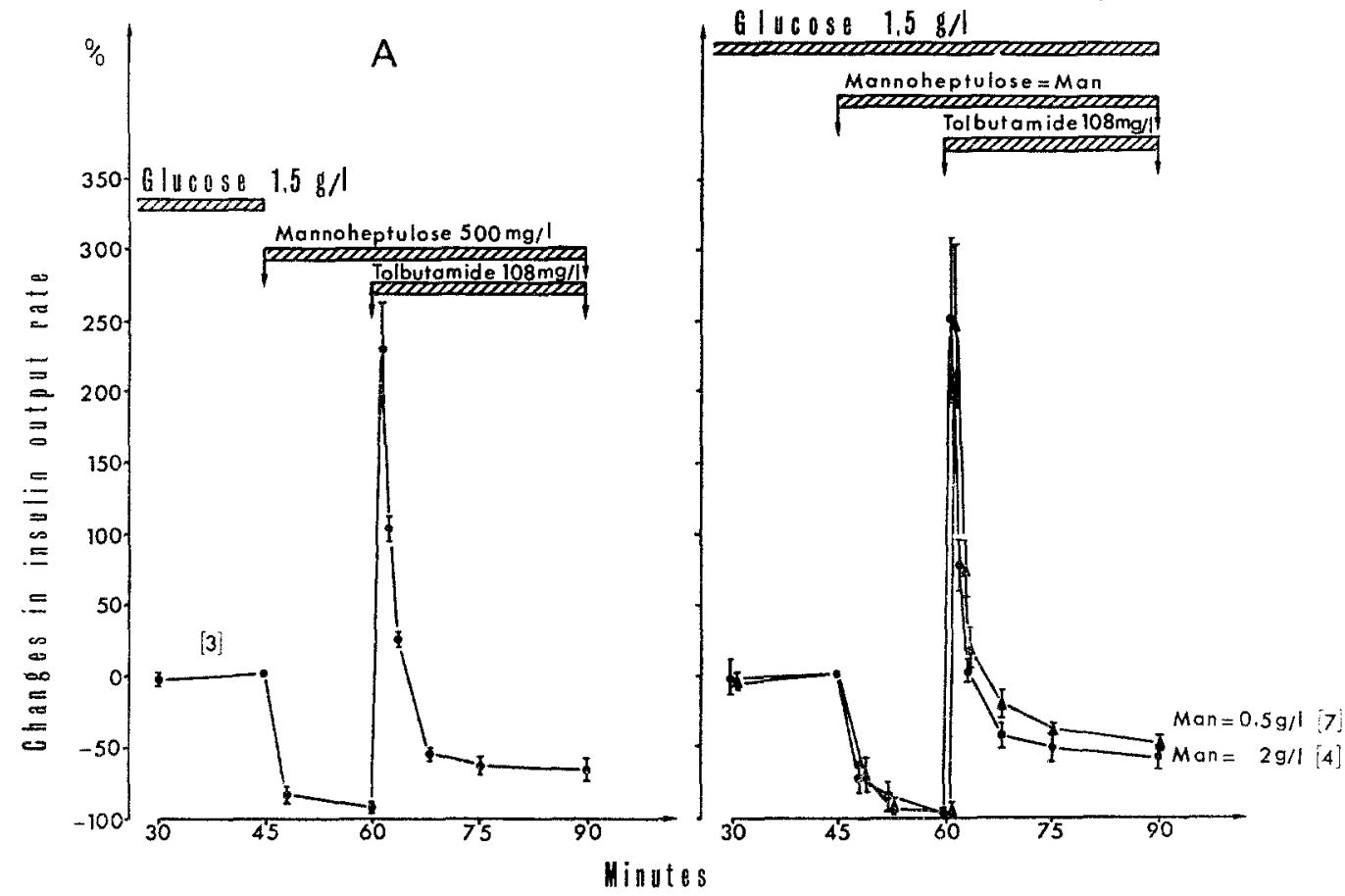

Fig. 3. Effect of tolbutamide $0.4 \mathrm{mM}(108 \mathrm{mg} / 1)$ in the presence of D-mannoheptulose $2.36 \mathrm{mM}(500 \mathrm{mg} / 1)$ or $9.44 \mathrm{mM}$ $(2000 \mathrm{mg} / \mathrm{l})$ on the secretion of insulin of the isolated and perfused rat pancreas. Graph A: Action in the absence of glucose in the perfusion medium. Graph B: Action in the presence of glucose $(1.5 \mathrm{~g} / 1)$. The number of pancreases si indicated in brackets

A

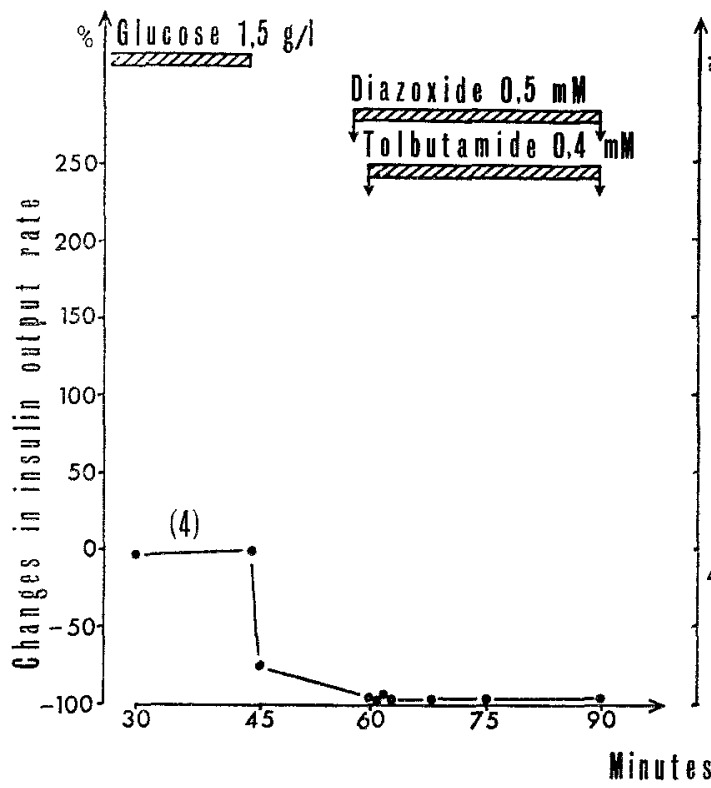

$B$

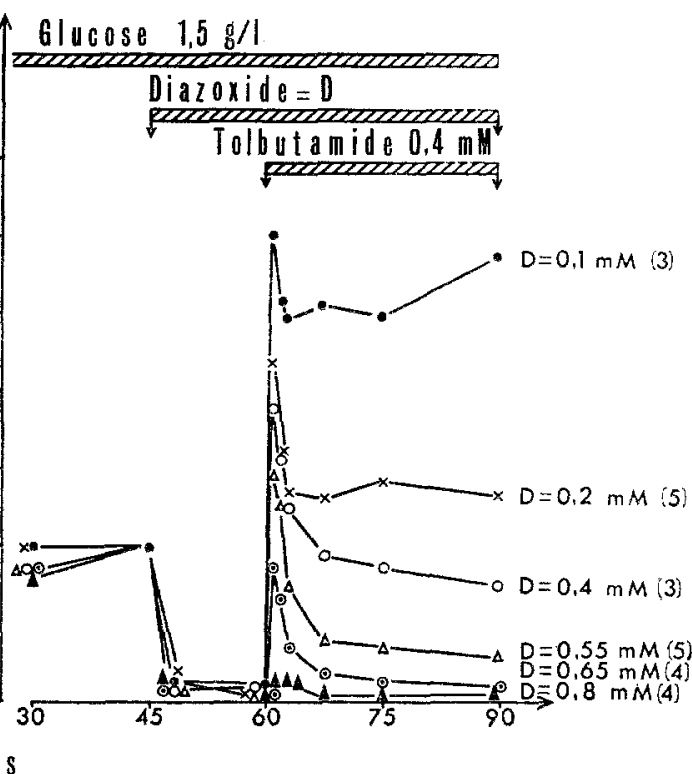

Fig. 4. Effect of tolbutamide $0.4 \mathrm{mM}(108 \mathrm{mg} / \mathrm{l})$ in the presence of diazoxide on the secretion of insulin of the isolated and perfused rat pancreas. Diazoxide was used at different concentrations: $0.1 \mathrm{mM}(23 \mathrm{mg} / \mathrm{l})-0.2 \mathrm{mM}$ $(46 \mathrm{mg} / 1)-0.4 \mathrm{mM}(92 \mathrm{mg} / 1)-0.55 \mathrm{mM}(126.5 \mathrm{mg} / \mathrm{l})-0.65 \mathrm{mM}(149.5 \mathrm{mg} / \mathrm{l})$ and $0.8 \mathrm{mM}(184 \mathrm{mg} / 1)$. Graph A: Action in the absence of glucose in the perfusion medium. Graph B: Action in the presence of glucose (1.5 g/l). The number of pancreases used for the establishment of each curve is indicated in parenthesis 
maximum one minute after the beginning of the perfusion. This first phase is followed by a second phase of lesser intensity but of longer duration, as we have previously shown $[6,11,9]$. This same phenomenon had also been described in vitro by Grodsky et al. [3].

When tolbutamide acts in the presence of glucose (1.5 g/l) (Figure 1), the first phase of intense and rapid. secretion previously described still occurs, but the subsequent behaviour of the pancreas is different from that observed in the absence of glucose. Insulin secretion remains increased during the $30 \mathrm{~min}$ infusion of tolbutamide, that is to say, during the second phase of the secretion of insulin.

As we have previously shown $[6,7,8,9,11]$, the magnitude of the secretion during the second phase is a function of the concentration of glucose in the medium; there exists a potentiating effect between the action of glucose and that of tolbutamide during this phase.

The presence of glucose is therefore necessary in order that tolbutamide maintain a prolonged, elevated secretion.

Although the experimental conditions used by Haupt et al. [5] are quite different from our own, it would seem that their results obtained in man could be correlated with our own.

Our "in vitro" experiments clearly demonstrate that the stimulating action of tolbutamide on the secretion of insulin presents two components: one that is independent of the presence of glucose in the medium that bathes the beta cells; the other that is dependent upon the presence of glucose in the medium. These results have been previously described by us [12].

The experiments carried out with D-mannoheptulose underline the fact that this substance acts on the secretion of insulin provoked by glucose at very weak concentrations (Figure 2). In fact, between $0.0236 \mathrm{mM}$ and $2.36 \mathrm{mM}$ it manifests an inhibitory effect, that is a function of the logarithm of its concentration, on the stimulating action of $8.33 \mathrm{mM}(1.5 \mathrm{~g} / 1)$ of glucose. We wish to emphasize the fact that these concentrations are lower than those previously used by different authors $[2,15]$.

D-mannoheptulose inhibits the phosphorylation of glucose [1] and therefore its metabolism. On the other hand according to certain authors, it could prevent the binding of glucose to specific receptors located on the membrane of the beta cell of the islets of Langerhans $[13,14]$. When mannoheptulose was used at a concentration $(500 \mathrm{mg} / \mathrm{l})$ sufficient to inhibit the action of glucose (Figure 3), it opposed the component of the stimulating effect of tolbutamide that was gluco-dependent, but it was incapable of modifying the component that was independent of the presence of glucose. In fact, the first phase of stimulation appeared just as intense whether or not mannoheptulose was present in the medium.

The results obtained with diazoxide have enabled us to note a difference in behavior between this substance and mannoheptulose concerning the action of tolbutamide on the secretion of insulin.
Diazoxide opposed all of the simulating action of tolbutamide on the secretion of insulin. It suppressed the insulin response in the absence, as well as in the presence of glucose; that is to say, it opposed the two components of the action of tolbutamide.

Therefore, it seems that the inhibitory mechanisms that diazoxide and mannoheptulose exert on the secretion of insulin provoked by tolbutamide are different. The first is a direct antagonist of tolbutamide while the second is only an indirect antagonist, its action being mediated by its effect on the metabolism of glucose.

\section{References}

1. Coore, H.G., Randle, P.J.: Regulation of insulin secretion studied with pieces of rabbit pancreas incubated in vitro. Biochem. J. 93, 66-78 (1964).

2. Coore, H.G., Randle, P.J., Simon, E., Kraicer, P.F., Shelensnyak, M.C.: Block of insulin secretion from the pancreas by D-mannoheptulose. Nature 197, $1264-1266$ (1963).

3. Grodsky, G.M., Bennett, L.L., Smith, D., Nemechek, $\mathrm{K}$. : The effect of tolbutamide and glucose on the timed release of insulin from the isolated perfused pancreas. In: "Tolbutamide after ten years," Edit. W.J.W. Butterfield and $W$. van Westering, pp. 11-21. Amsterdam: Excerpta Medica Foundation 1967.

4. Hales, C.N., Randle, P.J.: Immuno-assay of insulin with insulin-antibody precipitate. Biochem. J. 88, 137-146 (1963).

5. Haupt, E., Köberich, W., Beyer, J., Schöffling, K.: Pharmacodynamic aspects of tolbutamide, glibenclamide, glibornuride and glisoxepide. II. Repeated administration in combination with glucose. Diabetologia 7, 455-460 1971 .

6. Loubatières, A.: Stimulators and inhibitors of insulin secretion: physiological and pharmacological interferences, synergisms and antagonisms. In "Mechanism and Regulation of Insulin Secretion" II Capri Conference $8-9$ avril 1968, 220-255, Rédacteurs: $R$. Levine et E.F. Pfeiffer, Il Ponte, Milano.

7. Loubatières, A., Mariani, M.M., Chapal, J.: Effets de concentrations croissantes de glucose sur l'insulinosécrétion. Synergie entre glucose et sulfamides hypoglycémiants. C. R. Soc. Biol. 162, 1575-1580 (1968).

8. Loubatières, A., Mariani, M.M., Chapal, J.: Etude de la synergie ontre lo glucoso et le tolbutamide dans les limites physiopathologiques de la glycómie. C.R. Acad. Sci. (Paris), série D 269, 1460-1463 (1969).

9. Loubatières, A., Mariani, M.M., Chapal, J.: Insulinosécrétion étudiée sur le pancréas isolé et perfusé du rat. I. Synergie entre glucose et sulfamides hypoglycémiants. Diabetologia 6, 457-466 (1970).

10. Loubatiòres, A., Mariani, M.M., Ribes, G., De Malbose, H., Chapal, J.: Etude expérimentale d'un nouveau sulfamide hypoglycémiant particulièrement actif, lo HB 419 ou glibenclamide. I. Action bêtacytotrope et insulino-sécrétrice. Diabetologia 5, 1-10 (1969).

11. Mariani, M.M.: The action of sulfonylureas on the insulin secretion of the perfused rat pancreas. In "Pharmacokinetics and Mode of action of Oral hypoglycaemic Agents" III Capri Conference, 2-3 avril 1969, 256-270. Rédacteurs: A. Loubatières et A.E. Renold. II Ponte, Milano. 
12. Mariani, M.M., Loubatières, A. : Récentes expériences concernant l'antagonisme entre certains sulfamides hypoglycémiants et le diazoxide. International Meeting on "Hypoglycaemia and Diazoxide", Venise, $15-16$ octobre 1971, (in press).

13. Matschinsky, F.M., Ellerman, J.E., Landgraf, R., Krzanowski, J., Kotler-Brajtburg, J., Fertel, R.: Quantitative histochemistry of glucose metabolism in the islets of Langerhans. In: "Recent advances in quantitative histo and cytochemistry", 143-179. U.C. Dubach and U. Schmidt édit. Bern: Hans Huber Verlag 1970.
14. Scheynius, A., Täljedal, I.B.: On the mechanism of glucose protection against alloxan toxicity. Diabetologia 7, 252-255 1971 .

15. Sussman, K.E., Georg, R.H.: Metabolic control of insulin-secretion. Acta Diabet. Lat. 7, 889-908 (1970).

Prof. A. Loubatières Faculté de Médecine Institut de Biologie Boulevard Henri IV

Montpellier

France 